\title{
PELAKSANAAN KEWAJIBAN PEMBERI FIDUSIA SEBAGAI YANG MENGUASAI BENDA JAMINAN FIDUSIA PADA PT INDOMOBIL FINANCE INDONESIA CABANG TABANAN*
}

\author{
Oleh: \\ Ni Putu Indianita Cahyanti** \\ Marwanto*** \\ I Nyoman Mudana****
}

Bagian Hukum Bisnis Fakultas Hukum Universitas Udayana

\begin{abstract}
Abstrak
Ketentuan fidusia yang memberikan debitur kuasa untuk tetap menguasai objek jaminan disisi lain menyebabkan dilanggarnya kewajiban debitur dimasa depan. Dalam prakteknya tidak jarang terjadi permasalaan seperti benda jaminan dialihkan, digadaikan atau disewakan oleh debitur tanpa sepengetahuan krediturnya. Penelitian ini membahas mengenai kewajiban pemberi fidusia sebagai yang menguasai benda jaminan di PT Indomobil Finance Indonesia Cabang Tabanan dan upaya penyelesaian pelanggaran kewajiban pemberi fidusia sebagai yang menguasai objek jaminan di PT Indomobil Finance Indonesia Cabang Tabanan.

Metode yang digunakan dalam skripsi ini adalah metode penelitian hukum empiris dengan pendekatan perundangundangan dan pendekatan fakta. Penelitian ini menggunakan data primer dan data sekunder. Tujuan penulisan ini adalah untuk memberikan kontribusi keilmuan yang berhubungan dengan pelaksanaan kewajiban pemberi fidusia.

Hasil dari penelitian ini adalah kewajiban-kewajiban debitur sebagai yang menguasai objek jaminan fidusia di PT Indomobil Finance Indonesia Cabang Tabanan belum terlaksana dengan baik karena adanya pelanggaran kewajiban yang dilakukan oleh

\footnotetext{
*Penulisan karya ilmiah yang berjudul Pelaksanaan Kewajiban Pemberi Fidusia Sebagai Yang Menguasai Benda Jaminan Fidusia Pada PT Indomobil Finance Indonesia Cabang Tabanan, Jurnal Ini Merupakan Ringkasan Skripsi.

${ }^{* *}$ Ni Putu Indianita Cahyanti, (1503005086), Mahasiswa S1 Reguler Pagi, Email: indianita116@gmail.com.

${ }^{* * *}$ Dr. Marwanto, SH.M.,Hum, Dosen Tetap Fakultas Hukum Universitas Udayana.

${ }_{* * * *}^{*}$ I Nyoman Mudana, SH.,MH, Dosen Tetap Fakultas Hukum Universitas Udayana.
} 
debitur. Sedangkan upaya penyelesaian pelanggaran kewajiban debitur sebagai yang menguasai benda jaminan fidusia dilakukan dengan negosiasi, apabila upaya tersebut tidak membuahkan hasil maka akan ditempuh jalur litigasi.

\title{
Kata Kuci: Kewajiban, Pemberi Fidusia yang Menguasai Benda Jaminan, Jaminan Fidusia
}

\begin{abstract}
Fiduciary provisions that give the debtor the power to keep control of the collateral object on the other hand, it caused the debtor's liability to be violated in the future. In practice, it is not uncommon for objects to be transferred, mortgaged or leased by the debtor without the knowledge of the creditor. The purpose of this research is to find out more about the obligation of the fiduciary as the owner of collateral in PT Indomobil Finance Indonesia Cabang Tabanan and an attempt to resolve violations of the obligations of the fiduciary in PT Indomobil Finance Indonesia Cabang Tabanan.

The method used is an empirical legal research with a statutory approach and a factual approach. This research uses primary data and secondary data. The purpose of this writing is to provide scientific contributions related to the implementation of the obligations of fiduciary providers.

The results of this research are the obligations of the debtor in PT Indomobil Finance Indonesia Cabang Tabanan which have not been implemented properly due to a violation of the obligations carried out by the debtor. Meanwhile, the efforts to resolve violations of debtor's obligations are conducted through negotiations, if these efforts do not produce results, litigation will be taken.
\end{abstract}

\section{Keywords: Obligations, Giver of Fiduciary Who Control the Collateral Objects, Fiduciary}

\section{PENDAHULUAN}

\subsection{Latar Belakang}

Pemberian fasilitas pembiayaan diikuti dengan perjanjian pembiayaan. Biasanya perjanjian pembiayaan yang pada pokoknya perjanjian utang tersebut diikuti dengan sebuah perjanjian 
accesoir, yaitu perjanjian jaminan, khususnya menggunakan model jaminan fidusia. ${ }^{1}$

Berdasarkan Pasal 1 angka 2 Undang-Undang Nomor 42 Tahun 1999 Tentang Jaminan Fidusia, yang selanjutnya disebut UUJF, menyatakan bahwa,

Jaminan Fidusia ialah hak jaminan yang tetap berada dalam penguasaan Pemberi Fidusia atas benda bergerak baik yang berwujud ataupun yang tidak berwujud dan benda tidak bergerak. Benda tidak bergerak yang dimaksud khususnya bangunan yang tidak dibebani dengan hak tanggungan. Jaminan ini digunakan sebagai agunan bagi pelunasan utang tertentu, yang memberikan hak preference bagi penerima fidusia.

Hubungan hukum antara pemberi fidusia dan penerima fidusia dalam Perjanjian jaminan fidusia akan melahirkan hak dan kewajiban bagi para pihak. Pemberi fidusia diberi hak untuk tetap menguasai dan mempergunakan barangnya namun diwajibkan untuk menyerahkan hak kepemilikannya atas barang itu secara constitutum possesorium kepada kreditur. Constitutum Prossessorium artinya, dilakukan penyerahan terhadap hak milik dari suatu benda baik bergerak maupun tidak bergerak dengan janji, bahwa fisik bendanya tetap dipegang oleh pemberi jaminan. ${ }^{2}$

Berdasarkan Pasal 1977 ayat (1) Kitab Undang-Undang Hukum Perdata, yang selanjutnya disebut KUHPer, menyatakan bahwa, Baik benda bergerak yang tidak berbentuk, seperti bunga maupun piutang yang tidak harus dibayar maka yang menguasainya dianggap sebagai pemilik. Hal ini berarti seorang yang menguasai secara fisik suatu benda bergerak, dianggap

1Lidya Mahendra, et. al., 2016, "Perlindungan Hak Kreditur Dalam Adanya Pengalihan Benda Jaminan Oleh Debitur", Jurnal Magister Kenotariatan Universitas Udayana, Vol. 1 No.02, ISSN : 2502-7573, h. 268. https://ojs.unud.ac.id/index.php/ActaComitas/article/view/24959 diakses pada tanggal 19 Maret 2019.

2Rachmadi Usman, 2009, Hukum Jaminan Keperdataan, Sinar Grafika, Jakarta, h. 152. 
pemilik benda tersebut, kecuali dapat dibuktikan sebaliknya. Sehingga dengan adanya pengaturan tersebut pihak ketiga bisa saja memandang pemberi fidusia yang menguasai benda secara fisik sebagai pemiliknya.

Ketentuan Pasal 1977 ayat 1 KUHPer tidak jarang disalahgunakan oleh debitur yang tidak baik. Ketentuan fidusia yang memberikan debitur kuasa untuk tetap menguasai objek jaminan disisi lain juga memberikan peluang bagi dicederainya perjanjian dan timbulnya wanprestasi oleh debitur dimasa depan. Dengan penguasaan benda jaminan ditangan debitur, besar kemungkinan benda jaminan untuk dialihkan, disewakan, digadaikan atau dijual kepada pihak lain tanpa sepengetahuan kreditur. Dalam praktiknya susah untuk mengawasi benda jaminan fidusia yang berada dalam penguasaan debitur karena pihak debitur dapat berbuat apa saja lebih-lebih sudah mengetahui dirinya tidak akan mampu untuk melakukan kewajiban untuk melaksanakan prestasinya sesuai dengan perjanjian yang dilakukan. ${ }^{3}$

Padahal menurut Pasal 23 UUJF yang menyatakan bahwa, Pemberi Fidusia dilarang untuk mengalihkan, menggadaikan, atau menyewakan objek jaminan fidusia yang bukan merupakan benda persediaan, kepada orang lain tanpa persetujuan tertulis dari kreditur. Hal ini dimaksudkan sebagai kewajiban debitur untuk menjaga atau menjamin jika pada saat debitur cidera janji kreditur dapat melakukan eksekusi. Namun, dalam pelaksanaannya, banyak terjadi kasus pelanggaran kewajiban pemberi fidusia sebagai yang menguasai benda jaminan, berupa penggadaian

3I Made Sarjana et.al, 2015, "Menguji Asas Droit De Suite Dalam Jaminan Fidusia", Jurnal Magister Hukum Udayana, Vol. 4, No. 3, ISSN 2302-528X. https://ojs.unud.ac.id/index.php/jmhu/article/view/18048/11719 diakses pada tanggal 26 Maret 2019. 
objek jaminan kepada pihak lain. Kasus tersebut terjadi di PT Indomobil Finance Indonesia Cabang Tabanan.

Berdasarkan uraian diatas, maka akan dikaji suatu masalah dengan judul "Pelaksanaan Kewajiban Pemberi Fidusia Sebagai Yang Menguasai Benda Jaminan Fidusia Pada PT Indomobil Finance Indonesia Cabang Tabanan".

\subsection{Tujuan Penulisan}

Penulisan jurnal ilmiah ini dimaksudkan untuk mengetahui pelaksanaan kewajiban pemberi fidusia sebagai yang menguasai benda jaminan fidusia di PT Indomobil Finance Indonesia Cabang Tabanan serta upaya penyelesaian pelanggaran kewajiban pemberi fidusia sebagai yang menguasai objek jaminan di PT Indomobil Finance Indonesia Cabang Tabanan.

\section{ISI MAKALAH}

\subsection{Metode Penelitian}

Penulisan ini menggunakan metode penelitian hukum empiris. Penelitian hukum empiris adalah penelitian yang tujuannya untuk melihat bekerjanya hukum dalam prakteknya di masyarakat. ${ }^{4}$ Jenis pendekatan yang digunakan adalah pendekatan perundang-undangan dan pendekatan fakta. Pendekatan perundang-undangan adalah pendekatan yang dilakukan dengan mengkaji semua peraturan-peraturan yang berkaitan dengan permasalahan hukum yang ditangani. ${ }^{5}$ Pendekatan fakta adalah pendekatan yang melihat fakta-fakta dan

4Bahder Johan Nasution, 2008, Metode Penelitian Ilmu Hukum, CV. Mandar Maju, Bandung, h. 123.

${ }^{5}$ Amiruddin dan Zainal Asikin, 2016, Pengantar Metode Penelitian Hukum, PT RajaGrafindo Persada, Jakarta, h.164. 
penerapan hukum yang ada di lapangan. ${ }^{6}$ Data yang digunakan dalam penelitian ini adalah data primer dan data sekunder. Data primer adalah data yang diperoleh dengan melakukan wawancara dengan narasumber di lapangan. 7 Data sekunder adalah data yang diperoleh melalui penelitian kepustakaan. ${ }^{8}$ Analisis yang digunakan adalah analisis kualitatif.

\subsection{Hasil dan Analisis}

\subsubsection{Kewajiban Pemberi Fidusia Sebagai Pemegang Penguasaan Objek Jaminan Di PT Indomobil Finance Indonesia Cabang Tabanan}

Perjanjian menimbulkan hak dan kewajiban bagi para pihak yang menjadi subyek dalam perjanjian. Dalam perjanjian utang piutang, debitur akan diberikan persyaratan berupa jaminan kebendaan yang memadai untuk menjamin bahwa jika suatu saat debitur ingkar janji, maka objek jaminan akan dijadikan alternative pelunasan utang dengan jalan eksekusi. ${ }^{9}$ Untuk menjamin perikatan utang piutang tersebut antara konsumen dengan PT Indomobil Finance Indonesia Cabang Tabanan diikatlah dengan perjanjian jaminan fidusia.

Sebagai pemberi fidusia yang menguasai objek jaminan fidusia tentunya pemberi fidusia memiliki kewajiban-kewajiban terhadap kreditur atau penerima fidusia begitu juga terhadap objek jaminan. Bila didasarkan pada asas bahwa pemberi fidusia harus mempunyai itikad baik, maka pemberi fidusia sudah

${ }^{6} \mathrm{Ni}$ Komang Novi Artasari, 2016, "Pemberian Kredit dengan Jaminan Fidusia Sebagai Upaya Pengamanan Pihak Bank Pada Bank Pembangunan Daerah Bali Cabang Klungkung", Skripsi Fakultas Hukum Universitas Udayana, Denpasar, h. 18.

7Zainuddin Ali, 2016, Metode Penelitian Hukum, Sinar Grafika, Jakarta, h. 23.

8 Ibid.

9D.Y. Witanto, 2015, Hukum Jaminan Fidusia Dalam Perjanjian Pembiayaan Konsumen (Aspek Perikatan, Pendaftaran, dan Eksekusi), CV. Mandar Maju, Bandung, h.17 
seharusnya dan wajib untuk memelihara benda jaminan dengan sebaik-baiknya. ${ }^{10}$ Oleh karenanya pemberi fidusia tidak boleh melakukan fidusia ulang terhadap objek jaminan fidusia, maupun mengalihkan, menggadaikan atau menyewakan benda jaminan.

Menurut penjelasan Bapak I Gusti Made Wicaksana Kepala PT Indomobil Finance Indonesia Cabang Tabanan (wawancara tanggal 14 Desember 2018), adapun kewajiban pemberi fidusia di PT Indomobil Finance Indonesia Cabang Tabanan adalah:

a. Pemberi fidusia wajib untuk melakukan pemeliharaan dan menjaga objek jaminan fidusia.

Kewajiban pemberi fidusia untuk memelihara objek jaminan fidusia yang dimaksud adalah dengan melakukan semua tindakan yang diperlukan untuk pemeliharaan dan perbaikan atas objek jaminan fidusia dengan biaya sendiri, serta membayar pajak. Dikarenakan kewajiban pemberi fidusia untuk memelihara dengan baik objek jaminan, maka pemberi fidusia tidak berhak untuk melakukan fidusia ulang, menggadaikan atau mengalihkan objek jaminan fidusia kepada pihak ketiga tanpa persetujuan dari krediturnya.

b. Pemberi fidusia wajib melaporkan mengenai kondisi dan keberadaan objek jaminan kapanpun diminta oleh penerima fidusia.

c. Pemberi fidusia bertanggungjawab terhadap akibat dan resiko yang timbul dari penggunaan dan keadaan objek jaminan fidusia.

Apabila sebagian atau keseluruhan objek jaminan fidusia ada yang tidak dapat dipergunakan lagi, maka pemberi fidusia harus bertanggungjawab dengan mengganti bagianbagian yang tidak berfungsi dengan benda yang sejenis dan Didambakan, Alumni, Bandung, h.159-170. 
harganya setara. Selain itu penggantian terhadap objek jaminan fidusia harus disetujui oleh pihak PT Indomobil Finance Indonesia Cabang Tabanan sebagai penerima fidusia.

d. Objek Jaminan Fidusia wajib untuk diasuransikan oleh pemberi fidusia.

Asuransi wajib dilakukan kepada perusahaan asuransi yang telah ditunjuk atau disetujui oleh PT Indomobil Finance Indonesia Cabang Tabanan dengan jumlah pertanggungan serta dengan persyaratan yang telah ditentukan oleh penerima fidusia. Di dalam polis asuransi tersebut harus memuat kalimat bahwa apabila terjadi kerugian, maka uang pengganti kerugiannya harus diserahkan kepada PT Indomobil Finance Indonesia Cabang Tabanan. Selanjutnya akan diperhitungkan jumlah yang harus dibayar oleh pemberi fidusia kepada pihak finance berdasarkan perjanjian pembiayaan, sedangkan sisanya akan dikembalikan kepada debitur. Apabila ternyata uang dari perusahaan asuransi tidak mencukupi, maka pemberi fidusia wajib membayar sisa utangnya kepada pihak PT Indomobil Finance Indonesia Cabang Tabanan.

e. Pemberi fidusia berkewajiban membayar lunas utangnya apabila hasil penjualan objek jaminan fidusia tidak mencukupi untuk membayar utang tersebut.

Dalam hal debitur ingkar janji terhadap salah satu ketentuan dalam akta jaminan fidusia dan/atau salah satu ketentuan dalam perjanjian pembiayaan, terutama dalam hal pemberi fidusia/debitur terlambat melakukan pembayaran pada waktu yang ditentukan, maka objek jaminan fidusia akan dijual untuk melunasi utang. Namun, apabila hasil penjualan tidak mencukupi untuk melunasi utang debitur, 
maka pemberi fidusia wajib membayar pelunasan utang tersebut.

Meskipun kewajiban-kewajiban tersebut dengan jelas tercantum dalam peraturan perundang-undangan, perjanjian pembiayaan konsumen maupun dalam akta jaminan fidusia dan telah dijelaskan pula oleh pihak PT Indomobil Finance Indonesia Cabang Tabanan beserta dengan konsekuensinya, pada prakteknya sering debitur melakukan pelanggaran terhadap kewajiban tersebut. Salah satunya adalah debitur dengan nama I Komang Mei Adi Suwandana dengan Perjanjian Pembiayaan Konsumen dan Pengakuan Hutang (PPKDPH) nomor 245.1500930 dan Akta Jaminan Fidusia nomor: -683- yang telah menggadaikan objek jaminan fidusia kepada pihak lain, yaitu rentenir tanpa sepengetahuan dari kreditur. Padahal dengan jelas perbuatan tersebut dilarang dan konsekuensi dari perbuatan tersebut adalah sanksi pidana yang tercantum dalam Pasal 36 UUJF yang menentukan bahwa, terhadap pemberi fidusia yang melanggar ketentuan Pasal 23 ayat (2), akan dijatuhi sanksi pidana penjara paling lama 2 (dua) tahun dan denda paling banyak Rp. 50.000.000,- (lima puluh juta rupiah).

Berdasarkan penjelasan tersebut, menunjukkan pelaksanaan peraturan perundang-undangan belum sesuai dengan kenyataan di masyarakat, sehingga dapat disimpulkan pelaksanaan kewajiban pemberi fidusia sebagai yang menguasai benda jaminan belum berjalan dengan baik.

\subsubsection{Upaya Penyelesaian Pelanggaran Kewajiban Pemberi Fidusia Pada PT Indomobil Finance Indonesia Cabang Tabanan}

Pelanggaran kewajiban yang dilakukan oleh debitur di PT Indomobil Finance Indonesia Cabang Tabanan sebagai yang 
menguasai benda jaminan adalah menggadaikan benda yang menjadi objek jaminan fidusia.

Menurut penjelasan Bapak Kadek De Adnyana sebagai JFT (Penyuluh Hukum Pertama) di Kementrian Hukum dan HAM Kantor Wilayah Bali (wawancara tanggal 25 Januari 2019), penyelesaian yang dapat dilakukan apabila dilakukan pelanggaran kewajiban oleh debitur sebagai yang menguasai objek jaminan dengan digadaikannya jaminan, secara umum yaitu pertama dilakukan negosiasi secara kekeluargaan (perundingan/ musyawarah). Apabila tetap tidak ada itikad baik dari debitur, maka pada umumnya kreditur akan langsung melaporkan kasus tersebut ke kantor polisi. Beliau juga menambahkan bahwa, selama debitur melakukan kewajiban mutlaknya untuk membayar utangnya maka meskipun objek jaminan digadaikan, disewakan, dijual maupun dialihkan tidak akan menjadi masalah. Hal ini akan menjadi masalah apabila debitur tidak melakukan pembayaran sesuai dengan yang diperjanjikan.

Kasus tersebut tentunya perlu diselesaikan agar kreditur tidak mengalami kerugian yang lebih besar lagi. Berdasarkan penjelasan Bapak I Gusti Made Putra Wicaksana (wawancara tanggal 14 Desember 2018), proses penyelesaian dari kasus tersebut yaitu dimulai dari pertama ketika debitur terlambat membayar angsuran yang harusnya dibayarkan setiap bulannya akan dilakukan follow up berupa kunjungan oleh kolektor untuk melakukan penagihan dan menegosiasikan kapan debitur akan melakukan pembayaran. Biasanya debitur akan diberi jangka waktu 2 hari, tetapi apabila debitur menjanjikan membayar pada tanggal tertentu, maka akan dilakukan kunjungan pada tanggal tersebut. 
Apabila masih tetap tidak dilakukan pembayaran selama waktu 9 hari sejak tanggal jatuh tempo, maka dari pihak PT Indomobil Finance Indonesia Cabang Tabanan akan menerbitkan Surat Pemberitahuan penagihan yang pertama untuk segera melakukan pembayaran. Apabila lewat dari 15 hari maka akan diterbitkan Surat Pemberitahuan yang kedua, kemudian dalam tenggang waktu 21 hari sejak tanggal jatuh tempo belum ada pembayaran maka akan diterbitkan Surat Pemberitahuan ketiga. Dimana dalam proses tersebut diketahui bahwa objek jaminan yang seharusnya setelah dikeluarkan surat pemberitahuan sebanyak 3 kali tersebut dapat menjadi bukti untuk dilakukannya eksekusi atau penarikan objek jaminan oleh pihak PT Indomobil Finance Indonesia Cabang Tabanan, ternyata telah digadaikan.

Seharusnya, jika didasarkan pada asas droit de suit yang terdapat dalam Pasal 20 UUJF, yang menentukan bahwa, Jaminan fidusia akan selalu mengikuti benda yang menjadi objek jaminan fidusia di tangan siapapun benda tersebut berada, kecuali pengalihan atas benda persediaan yang menjadi objek jaminan. Maka dimanapun benda berada kreditur tetap dapat mengeksekusinya.

Namun, debitur menolak untuk memberitahukan dimana keberadaan objek jaminan. Sehingga kreditur tidak dapat melakukan eksekusi objek jaminan. Oleh karenanya dilayangkan somasi kepada debitur. Pengajuan somasi diajukan pada tim legal di Jakarta. Kemudian setelah di proses maka akan dikirimkan Somasi pertama kepada debitur. Setelah 7 hari maka akan dikirimkan somasi yang kedua. Setelah 7 hari berikutnya akan dikirimkan somasi ketiga. Selama somasi dilayangkan, pihak kreditur masih melakukan negosiasi kembali dengan meminta agar debitur menebus mobil yang telah digadaikan kepada 
rentenir. Jika, setelah ditebus unitnya dan tidak sanggup lagi melanjutkan kredit, maka akan dilakukan penarikan unit. Pada kasus ini debitur tidak sanggup menebus unit kembali karena masalah ekonomi.

Permasalahannya debitur tidak bersedia untuk memberitahukan tempat dimana ia telah menggadaikan objek jaminan fidusia, sehingga tidak diketahui dimana keberadaan unit dan eksekusi pun tidak dapat dilakukan. Setelah dilakukan proses negosiasi yang diperlukan, ternyata debitur tidak memiliki itikad baik, maka dari pihak PT Indomobil Finance Indonesia Cabang Tabanan menempuh upaya hukum (penyelesaian melalui pengadilan). Setelah putusan pengadilan nomor:110/Pid.sus/2017/PN.Nga, mobil yang sebelumnya disita sebagai barang bukti dikembalikan kepada PT Indomobil Finance Indonesia Cabang Tabanan.

Berdasarkan ketentuan Pasal 29 UUJF dan Pasal 7 Akta Jaminan Fidusia Nomor -683-, objek jaminan fidusia dijual sesuai dengan harga pasaran untuk menutupi utang-utang debitur. Apabila dalam penjualan tersebut terdapat sisa maka akan dikembalikan kepada pihak debitur. Hal ini telah sesuai dengan Pasal 34 ayat (1) UUJF, yang menyatakan bahwa, apabila hasil penjualan benda jaminan melebihi nilai penjaminan, penerima fidusia wajib untuk mengembalikan kelebihan hasil penjualan kepada pemberi fidusia. Namun, apabila hasil penjualan tidak mampu menutupi utang debitur, maka kekurangan tersebut akan menjadi kerugian perusahaan. Hal ini dikarenakan bahwa meskipun penagihan dilakukan, debitur juga tetap tidak akan melakukan pembayaran dan untuk mengurangi kerugian perusahaan yang lebih banyak. 
Dalam kasus ini hasil penjualan objek jaminan tidak mencukupi pelunasan utang debitur sehingga menyebabkan kerugian perusahaan.

\section{PENUTUP}

\subsection{Kesimpulan}

1. Pelaksanaan kewajiban pemberi fidusia sebagai yang menguasai benda jaminan fidusia di PT Indomobil Finance Indonesia Cabang Tabanan belum terlaksana secara maksimal dikarenakan adanya pelanggaran kewajiban yang dilakukan oleh debitur yang tidak bertanggung jawab.

2. Adapun penyelesaian yang ditempuh melalui negosiasi, dan apabila, penyelesaian secara damai tidak tercapai maka upaya terakhir yang dapat ditempuh ialah melalui pengadilan.

\subsection{Saran}

1. Kepada pihak debitur dengan segala itikad baik agar lebih bertanggungjawab dalam menggunakan objek jaminan dan memperhatikan kewajiban-kewajiban yang telah disepakati serta tidak melakukan tindakan yang dilarang sehingga tidak terjadi kesalahan dikemudian hari yang dapat merugikan kedua belah pihak.

2. Kepada pihak ketiga agar selalu melakukan pengecekan secara teliti terhadap dokumen kepemilikan yang sah setiap benda yang akan dijaminkan kepadanya sehingga tidak terjadi lagi penggadaian objek jaminan fidusia yang dapat merugikan pihak ketiga dan kreditur, dan kepada PT Indomobil Finance Indonesia Cabang Tabanan hendaknya memberikan tanda pada benda jaminan fidusia berupa pemberian stiker fidusia pada setiap objek jaminan, serta 
rutin untuk melakukan pengawasan objek jaminan, paling tidak sebulan sekali sehingga dapat memperkecil masalah dan kerugian.

\section{Buku}

\section{DAFTAR PUSTAKA}

Amiruddin dan Zainal Asikin, 2016, Pengantar Metode Penelitian Hukum, PT RajaGrafindo Persada, Jakarta.

Bahder Johan Nasution, 2008, Metode Penelitian Ilmu Hukum, CV. Mandar Maju, Bandung.

Rachmadi Usman, 2009, Hukum Jaminan Keperdataan, Sinar Grafika, Jakarta.

Tan Kamello, 2004, Hukum Jaminan Fidusia Suatu Kebutuhan yang Didambakan, Alumni, Bandung.

Witanto, D.Y., 2015, Hukum Jaminan Fidusia Dalam Perjanjian Pembiayaan Konsumen (Aspek Perikatan, Pendaftaran, dan Eksekusi), CV. Mandar Maju, Bandung.

Zainuddin Ali, 2016, Metode Penelitian Hukum, Sinar Grafika, Jakarta.

\section{Skripsi}

Ni Komang Novi Artasari, 2016, "Pemberian Kredit dengan Jaminan Fidusia Sebagai Upaya Pengamanan Pihak Bank Pada Bank Pembangunan Daerah Bali Cabang Klungkung", Skripsi Fakultas Hukum Universitas Udayana, Denpasar.

\section{Jurnal}

Lidya Mahendra et. al., 2016, "Perlindungan Hak-Hak Kreditur Dalam Hal Adanya Pengalihan Benda Jaminan Oleh Pihak Debitur", Jurnal Magister Kenotariatan Universitas Udayana, Vol. 1 No.02, ISSN : 2502-7573. https://ojs.unud .ac.id/index.php/ActaComitas/article/view/24959 diakses pada tanggal 19 Maret 2019. 
I Made Sarjana et.al, 2015, "Menguji Asas Droit De Suite Dalam Jaminan Fidusia", Jurnal Magister Hukum Udayana, Vol. 4, No. 3, ISSN 2302-528X. https://ojs.unud.ac.id/index.php/ jmhu/article/view/18048/11719 diakses pada tanggal 26 Maret 2019.

\section{Peraturan Perundang-undangan}

Kitab Undang-Undang Hukum Perdata.

Indonesia, Undang-Undang Tentang Jaminan Fidusia, UndangUndang Nomor 42 Tahun 1999, Lembaran Negara Republik Indonesia Tahun 1999 Nomor 168, Tambahan Lembaran Negara Repubik Indonesia Nomor 3889. 